\title{
BIOECONOMY AS A CONCEPT FOR THE DEVELOPMENT OF AGRICULTURE AND AGRIBUSINESS
}

\author{
MIECZYSŁAW ADAMOWICZ
}

\begin{abstract}
The subject of the paper is the concept of bioeconomy as a new, combined method to perceive the functioning of various sectors of the national economy producing and processing biological resources. Based on discussions in the literature and documents of the European institutions, bioeconomy has been presented as a theoretical concept and its essence and ways of defining the scope and size of bioeconomy, and the opportunities and risks associated with bioeconomy. The directions and areas of action as well as current strategies to support the development of sustainable bioeconomy and its relation to the circular economy model have been shown. Results from analyses show that bioeconomy is a promising concept for the development of agriculture, agribusiness, forestry, and other sectors producing and using bio-based raw materials. For making use of the real opportunities of bioeconomy, it is essential to have national and regional bioeconomy development strategies in place and to develop an efficient design and management system at the level of enterprises, sectors, and regional systems.
\end{abstract}

Keywords: bioeconomy, circular economy, sustainable development, development strategies.

Kody JEL: Q01, 10, Q18, Q20, Q57.

Mieczysław Adamowicz, PhD, DSc, ProfTit, Pope John Paul II State School of Higher Education in Biala Podlaska; ul. Sidorska 95/97, 21-500 Biała Podlaska, Poland (m.adamowicz@pswbp.pl). ORCID iD: 0000-0002-1164-4966. 


\section{Introduction}

Modern agriculture in Poland functions under the conditions of various internal and external factors. External processes of globalization and international integration are of key importance for the development of agriculture, the entire agri-food complex, and for the socio-economic and cultural development of rural areas. While the phenomena governing globalization are autonomous and cannot be shaped by national economic entities and authorities, Poland, since having become a member of the European Union, has certain, yet limited, possibilities of influencing the course of European integration. This influence can be exerted by affecting the shape of the Common Agricultural Policy and other important Community policies for agriculture and rural areas. Through various forms of support and strategic development programs, thanks to these policies, it is possible to promote new development concepts which may include bioeconomy, a concept going far beyond the limits of agriculture and agribusiness, yet strongly dependent on these sectors.

The objective of the paper is to present the conditions for its development, the forms of occurrence, and the results of bioeconomy development processes, with particular consideration given to the challenges for the state's economic policy, which result from these processes. The paper has been drawn up based on the examination of scientific literature, official documents of the European Union and other international institutions, and the author's own observations.

\section{Bioeconomy as a new theoretical concept}

\section{The essence of and approaches to bioeconomy}

The concept of sustainable development, introduced in the $70 \mathrm{~s}$ of the $20^{\text {th }}$ century, is constantly expanded and adapted to ever-changing conditions and needs. Just like in its conception, today, sustainable development includes three major areas: economic, social, and environmental aspects. In the European Union, it is measured by several dozen indicators from ten thematic areas (Chciałowski, Stolarczyk and Tuka, 2016). More and more often, the assessment of the sustainability of development highlights the problem of depletion of fossil fuels as energy sources, and the need to shift to renewable energy sources and the reuse of materials. One of the most important renewable energy sources is biomass, which can be used to produce fuels and a wide range of other products. The production of these products will be possible using various physico-chemical technologies and biotechnologies, starting from genetic technologies through nanotechnology to technologies using synthetic biology (Hall, Ernsting, Lovera and Alvarez, 2012). When examining these issues, attention is concentrated on possible ways of limiting economic development. The concept of bioeconomy appears here, which can be considered part of biological resources and products (production using biological resources), as well as of biological processes (use of biological processes) for the production of products (Ratajczak, 2013). 
In general terms, bioeconomy can be perceived as a new analytical and cognitive concept, an emerging new complex sector of the economy, a trans-sectoral form of analysis, and a new application of previously known development concepts of agriculture and agribusiness (Adamowicz, 2017). The first approach to bioeconomy means that it is considered not as a new theoretical concept, but rather as a new analytical and cognitive concept in economics. Stemming from the needs of science and practice, and makes it easier for researchers to carry out a research process while providing practitioners with a possibility to learn the scope, essence, and nature of relationships among various components. The second approach shows that bioeconomy is a capacious, dynamically developing sector of the modern economy, using biological resources in economic processes, namely: living organisms, biotechnologies, and bioprocesses applied in agriculture, forestry, fisheries, and aquatic cultures to produce food, industrial products, including medicines and energy. According to forecasts, bioeconomy may become a new economic system which will help meet various sustainable development challenges. At the heart of bioeconomy, there is the biologization of economic processes where non-renewable resources are replaced by renewable biological resources produced in a sustainable manner without unnecessary waste. Therefore, bioeconomy is an advanced systemic innovation, a way to depart from the current economic model based on non-renewable raw materials and fuels. Bioeconomy includes three elements drawn from latent values in biological resources, bioprocesses, and biotechnologies in the form of: advanced knowledge of genetics and complex cellular processes; application of this knowledge to develop new production processes and products; practical application of biotechnology in various sectors of the economy (Leitao, 2016). In the third approach, bioeconomy is regarded as a form of smart measures as part of strategic planning and interdisciplinary financing of scientific and research activities and of using intellectual capital.

This paper is focused on presenting bioeconomy as a capacious and dynamically developing sector of the economy, using biological resources, such as living organisms, biotechnologies, bio-based products, and bioprocesses, in economic processes to produce new products and services. The production of these bio-based products is conducted in various sectors of the economy, e.g., agriculture, forestry, fisheries, aquacultures, and other sectors, and the use of new products goes far beyond the sphere of producing food. In operational terms, bioeconomy replaces non-renewable resources with resources obtained from biomass to produce food, fuel, chemicals, medicines, and other valuable products, while reducing and reusing waste and sequestering carbon dioxide. In this way, sustainable development is guaranteed and the economy can become a zero-waste circular economy.

\section{Theoretical foundations of bioeconomy}

Bioeconomy can be defined as an economy in which the major components of production - the manufacturing of materials, chemical products, and energy are based on biological and renewable resources (McCormick and Kautto, 2013). 
In production processes, bioeconomy uses biomass (biomatter) obtained from reproducible biological resources of plant and animal origin, which are processed in a mechanical, biochemical, or thermo-chemical manner. In addition to trees, shrubs, crops, and plantations, other resources are also used: algae and aquatic plants, primary waste and residues, secondary waste and residues, and successive generations of waste and residues. The use of biomass in economic processes allows for producing and using thermal energy, liquid fuels, chemicals, bio-based products, food and feed, cosmetics, and medicinal products.

This definition of bioeconomy was achieved in an evolutionary manner, starting from the original definition, formulated in 1997 by J. Enriquez and R. Martinez, which initiated an official interest in bioeconomy on the part of the European Union bodies and OECD. This interest resulted in a number of other definitions, formulated in various centers between 2005 and 2009, and then led to more developed definitions proposed by the European Commission in the period 2010-2012. The definitions created at that time have not lost their validity, however, are complemented by new elements. This important new element highlights the importance of the concept of circular economy. Numerous scientific institutions, national and international organizations involved in conducting innovative research in economic practice as well as national governments creating national bioeconomy development strategies contributed to disseminating various definitions of bioeconomy.

One of the previous definitions by Enriquez and Martinez stated that bioeconomy encompasses all economic activity derived from scientific and/or research activity focused on understanding mechanisms and processes at the genetic/molecular level and its application to the industrial process (Enriquez and Martinez, 1998). The first stage of developing the concept was associated with the dynamic development and achievements of biology and biotechnology. Later, attention was paid to the links between bioeconomy and the natural environment, i.e., eco-development and sustainable development. The definition formulated in 2005 by the European Commission's Directorate-General for Research states that "bioeconomy is the sustainable, eco-efficient transformation of renewable biological resources into food, energy and other industrial products." (EC DG Research, 2005). Following this path, the EC DG Research elaborated on the concept of bioeconomy by specifying that it contains all production systems involving biophysical and biochemical processes, and thus includes all life sciences and related generic technologies necessary to make useful products, applications of biotechnology in agriculture and industry (Table 1). Bioeconomy also encompasses bio-refineries, the production of bio-energy and bio-chemicals, novel forms of land and sea usage to create public goods as well as the use of materials generally regarded as waste (EC DG Research, 2006). When defining bioeconomy in 2006, the OECD included its position in the development of policies. The organization proposed that bioeconomy is "the aggregate set of economic operations in a society that use the latent value incumbent in biological products and processes to capture new growth and welfare benefits for citizens and nations" (OECD, 2006). In 2009, the OECD said that bioeconomy means 
"transforming life science knowledge into new, sustainable, eco-efficient and competitive products." It was therefore pointed out that bioeconomy should be perceived as a reality in which biotechnologies are an important factor affecting the economic growth. By developing this concept in the OECD (2009), it was assumed that bioeconomy contains three elements:

- the use of advanced knowledge about genes and cellular processes for programming and developing new processes and products,

- the use of renewable biomass and efficient bioprocesses for stimulating sustainable production,

- the integration of biotechnological knowledge for its application in a wide range of sectors.

The evidence provided by the OECD was that biotechnologies could solve many global health- and nutrition-related problems and the OECD also suggested that biotechnologies used in bioeconomy would enable significant changes in the global economy over 30 years.

Countries with well-developed agriculture and biotechnologies, as well as large natural biological resources, pointed to the development of knowledge-based bioeconomy. During the German Presidency of the European Union, a conference was organized in 2007 where it was proposed that the bioeconomy encompasses the production of renewable biological resources and their conversion into food, feed, medicines, and other bio-based products and energy, and this viewpoint has become popular in EU Member States (Cologne Paper, 2007). The visionary document developed at that conference stressed that biotechnology would be an essential element of the European economy by 2030. This document specifically suggested an increase in the share and importance of the so-called white biotechnology products (medicines, cosmetics, etc.) and bioenergy in industrial production in Europe (McCormick and Kautto, 2013).

While in 2007 the concept of bioeconomy was still relatively new and poorly disseminated, the rapid dissemination of the concept took place from 2010 to 2013, which was the result of activities from various European Union bodies. In the concept formulated in the Bio-Economy Technology Platforms (BECOTEPS) draft, in 2010, it was written that "bioeconomy means all sectors which derive their products from biomass" while Geoghegan-Quinn, Director of DG Research at the European Commission, added that it was also "this part of the economy that generates growth and jobs from the development, processing and use of biological resources in an environmentally sustainable manner" (Maciejczak and Hofreiter, 2013).

Between 2010 and 2011, the European Commission presented several other documents in which it presented a couple of more or less developed definitions of bioeconomy. In one of them, the DG Research defined bioeconomy as "production models based on biological processes and natural ecosystems using natural materials, which consume minimal amounts of energy without generating waste, as all waste resulting from one process is the material for the next and as a result it is reused in the ecosystem" (EC DG Research, 2011). 
Bioeconomy was defined in a similar manner in the European Union documents published in 2011 (Europa Bio, 2011; ETP, 2011), when bioeconomy was considered a sustainable production and processing of renewable mass into a wide range of products and food, medical, industrial and energy services or for various biological materials for direct using and in the form of raw materials for the manufacture of other products. A comprehensive set of definitions of bioeconomy have been drawn up by M. Maciejczak and K. Hofreiter (2013). This set, complemented by later concepts, is included in Table 1.

We can consider the definition formulated by the European Commission in 2012, on the occasion of developing a strategy for the use of renewable biological resources in various fields of the economy, as the most comprehensive and the most developed definition. According to this definition, bioeconomy means sustainable production of renewable biological resources and their processing into food products, feed, industrial goods, and into bioenergy, which is based on agronomy, ecology, food sciences, social sciences, biotechnology, nanotechnology, ICT and engineering and includes agriculture, forestry, fishing industry, food, cellulose and paper production as well as elements of the chemical, biotechnology, energy, and transport sector (EC DG Research, 2012).

Today, as confirmed by the findings of the Berlin Global Forum for Food and Agriculture (GFFA, 2015) held in 2015 and the so-called Global Bioeconomy Summit (GBS, 2015), bioeconomy is recognized as shaping human lives in conjunction with the environment through: restoration of natural resources and ecosystems, innovation and green growth, and growth taking into account social and health aspects. Therefore, bioeconomy should be considered a sustainable use of biological renewable resources to create goods and services for the purpose of meeting the needs of the current generation without compromising the ability of future generations to meet their own needs. Thus, bioeconomy should be characterized by sustainable development, considering food security, job creation, strengthening competitiveness, preserving environmental values, and guaranteeing long-term human welfare and health. Another Global Bioeconomy Summit, held in 2018, highlighted the role of bioeconomy in sustainable economic development (GBS, 2018). 
Selected definitions of bioeconomy

Table 1

\begin{tabular}{|c|c|c|}
\hline $\begin{array}{l}\text { Year of } \\
\text { publishing }\end{array}$ & $\begin{array}{l}\text { Author/ } \\
\text { institution }\end{array}$ & Method of defining bioeconomy \\
\hline 1997 & $\begin{array}{l}\text { Enriquez, } \\
\text { Martinez }\end{array}$ & $\begin{array}{l}\text { all economic activity derived from scientific and/or research activity focused on } \\
\text { understanding mechanisms and processes at the genetic/molecular levels and its } \\
\text { application to industrial process }\end{array}$ \\
\hline 2005 & $\begin{array}{l}\text { EC DG } \\
\text { Research }\end{array}$ & $\begin{array}{l}\text { the sustainable, eco-efficient transformation of renewable biological resources into } \\
\text { food, energy and other industrial products }\end{array}$ \\
\hline 2006 & $\begin{array}{l}\text { EC DG } \\
\text { Research }\end{array}$ & $\begin{array}{l}\text { all production systems involving biophysical and biochemical processes, and thus } \\
\text { includes all of the life sciences and related generic technologies necessary to make } \\
\text { useful products; applications of biotechnology in agriculture and industry, such for } \\
\text { bio-refineries, bio-energy and bio-chemicals, are an integral part of the bio-based } \\
\text { economy; it also includes novel forms of land and sea usage (such as those enhancing } \\
\text { ecosystems services and other public goods) as well as the use of materials currently } \\
\text { considered as wastes }\end{array}$ \\
\hline
\end{tabular}

\begin{tabular}{|c|c|c|}
\hline 2007 & $\begin{array}{l}\text { Cologne } \\
\text { Paper }\end{array}$ & $\begin{array}{l}\text { encompasses the production of renewable biological resources and their conversion } \\
\text { into food, feed, bio-based products and bioenergy }\end{array}$ \\
\hline 2007 & $\begin{array}{l}\text { DEFRA, } \\
\text { UK }\end{array}$ & $\begin{array}{l}\text { economic activities which capture the latent value in biological processes } \\
\text { and renewable bioresources to produce improved health and sustainable growth } \\
\text { and development }\end{array}$ \\
\hline 2009 & OECD & $\begin{array}{l}\text { transforming life science knowledge into new, sustainable, eco-efficient } \\
\text { and competitive products }\end{array}$ \\
\hline 2010 & BECOTEPS & all sectors which derive their products from biomass \\
\hline 2010 & $\begin{array}{l}\text { Geoghean } \\
\text { Quinn }\end{array}$ & $\begin{array}{l}\text { part of the economy that generates growth and jobs from the development, } \\
\text { processing and use of biological resources in an environmentally sustainable manner }\end{array}$ \\
\hline 2011 & $\begin{array}{l}\text { EC DG } \\
\text { Research }\end{array}$ & $\begin{array}{l}\text { production models based on biological processes and natural ecosystems using } \\
\text { natural materials, which consume minimal amounts of energy without generating } \\
\text { waste, as all waste resulting from one process is the material for the next } \\
\text { and as a result it is reused in the ecosystem }\end{array}$ \\
\hline 2012 & $\begin{array}{l}\text { The White } \\
\text { House }\end{array}$ & $\begin{array}{l}\text { economy based on the use of research and innovation in the biological } \\
\text { sciences to create economic activity and public benefit }\end{array}$ \\
\hline 2012 & $\begin{array}{l}\text { EC DG } \\
\text { Research }\end{array}$ & $\begin{array}{l}\text { an economy using biological resources from the land and sea as well as waste } \\
\text { including food wastes, as inputs to industry and energy production, it also covers } \\
\text { the use of bio-based processes to green industries }\end{array}$ \\
\hline 2012 & $\begin{array}{l}\text { EC DG } \\
\text { Research }\end{array}$ & $\begin{array}{l}\text { bioeconomy encompasses the production of renewable biological resources } \\
\text { and the conversion of these resources and waste streams into value added products } \\
\text { such as food, feed, bio-based products and bioenergy. The bioeconomy relies on } \\
\text { life sciences, agronomy, ecology, food science and social sciences, biotechnology, } \\
\text { nanotechnology, information and communication technologies (ICT), and engineering, } \\
\text { and includes the sectors of agriculture, forestry, fisheries, food, and pulp and paper } \\
\text { production, as well as parts of chemical, biotechnological and energy industries }\end{array}$ \\
\hline 2013 & $\begin{array}{l}\text { McCormick, } \\
\text { Kautto }\end{array}$ & $\begin{array}{l}\text { an economy where the basic building blocks for materials, chemicals } \\
\text { and energy are derived from renewable biological resources, such as plant } \\
\text { and animal sources }\end{array}$ \\
\hline 2015 & NORDEN & $\begin{array}{l}\text { sustainable production and use of natural resources, application } \\
\text { of an international and systemic approach as a basis for circular economy }\end{array}$ \\
\hline
\end{tabular}


cont. Table 1

\begin{tabular}{|c|c|c|}
\hline 2015 & GFFA & $\begin{array}{l}\text { shaping human lives in conjunction with the environment through: restoration } \\
\text { of natural resources and ecosystems, innovation and green growth, } \\
\text { and growth taking into account social and health aspects }\end{array}$ \\
\hline 2018 & GBS & $\begin{array}{l}\text { production, use, and regeneration of resources, including related knowledge, } \\
\text { results of research, and innovation, to provide information, products, processes, } \\
\text { and services within and across all economic sectors to achieve the sustainable } \\
\text { economic development }\end{array}$ \\
\hline
\end{tabular}

Source: own study based on: Maciejczak and Hofreiter, 2013.

\section{The scope and size of bioeconomy}

Bioeconomy can be perceived differently in different countries and in relation to different sectors of the economy. However, it is of a trans-sectoral nature. A common feature to consider, independent of the sector, is the perspective of innovation and economic benefits likely to result from its development, and the inherent risks accompanying this concept. Everywhere, bioeconomy requires support by state institutions established for this purpose. In production processes, bioeconomy uses biomass obtained from reproducible biological resources of plant and animal origin, which are processed in a mechanical, biochemical, or thermo-chemical manner. What is also used, in addition to trees, shrubs, crops, and plantations, are algae and aquatic plants, primary waste and residues, secondary waste and residues, and successive generations of waste and residues. The use of biomass in economic processes allows the use of thermal energy, liquid fuels, chemicals, bio-based products, food, feed, cosmetics, and medicinal products.

The concept of bioeconomy is based on the realities of economic life, which is deeply rooted in the past, but its prospects are conditional upon biological and technological progress. Once in the pre-industrial era, represented by agriculture, forestry, fisheries, and the processing of biological raw materials, bioeconomy was a naturally dominant sector of the economy. Today, a significant part of bioeconomy goes beyond sectors related to direct management of natural resources to the sphere of sectors of processing, industrial production, transport, trade, and consumption integrated by research and scientific activities and innovation. Bioeconomy includes a kind of value processing and creation chain, in which products from primary biomass production sectors go through processing sectors, trade and distribution chains, reach final users in the form of food and biomaterials for further production and industrial products and consumption, creating the whole circular economic system (Gołębiewski, 2013). These three elements: production of biomass, processing as well as production, distribution, and consumption are integrated through a system of creating and using knowledge and innovation.

The activity of bioeconomy is based on the production of biomass, which, as a renewable resource, is used for the production of food, feed, biofuels, and biobased products for consumption and functional purposes. In processing biomass into more complex and refined products, a key role is played by biotechnologies, various mechanical techniques, chemical technologies, and physical processes. 
Bioeconomy can be considered from a micro-, meso- and macro-economic perspective. Companies can specialize in the innovative production of various products and services related to living organisms for consumption and functional purposes. Regions can choose bioeconomy as a leading smart developmental specialization. Sectors and industries of bioeconomy are characterized by great innovation potential thanks to building on scientific knowledge, well-developed industrial technologies, and latent knowledge inherent in local communities. For a country, of importance are the issues of sustainable and rational use of resources, employment, and generation of domestic product.

Table 2

Bioeconomy of the European Union in 2015

\begin{tabular}{lccc}
\hline \multicolumn{1}{c}{ Sector } & $\begin{array}{c}\text { Employment } \\
\text { (million) }\end{array}$ & $\begin{array}{c}\text { Turnover } \\
\text { (billion EUR) }\end{array}$ & $\begin{array}{c}\text { Value added } \\
\text { (billion EUR) }\end{array}$ \\
\hline Total & 18.00 & 2,300 & 621 \\
Agriculture & 9.20 & 380 & 174 \\
Forestry & 0.5 & 50 & 24 \\
Fisheries and aquaculture & 0.20 & 12 & 7 \\
Food, drinks, and others & 4.60 & 1,153 & 233 \\
Textiles & 1.0 & 103 & 28 \\
Wood products, furniture & 1.60 & 174 & 47 \\
Paper & 0.60 & 187 & 46 \\
Chemicals, pharmaceuticals, plastic & 0.40 & 177 & 56 \\
Liquid fuels & 0.03 & 12 & 3 \\
Electricity & 0.01 & 11 & 3 \\
\hline
\end{tabular}

Source: EC 2018, European Commission's Knowledge Centre for Bioeconomy.

The figures on employment, turnover, and value added in the bioeconomy of the European Union in 2015 have been presented in Table 2. At the beginning of the second decade of the 21 st century, the value of (commodity) production sold related to bioeconomy in the European Union was estimated at EUR 2,079 trillion a year and reached EUR 2,300 trillion in 2015. Employment in the sector, amounting to 22 million people in 2010, was reduced to 18 million in 2015, accounting for $9-10 \%$ of labor resources used throughout the economy. In 2010, about $55 \%$ of employment in bioeconomy were in agriculture, $20 \%$ in the food industry, and nearly $14 \%$ in forestry. It should be noted that the effects of employment in agriculture in the form of turnover and value added are not fully included among the effects of this sector, a large part is transferred to other sectors and is visible in the value of production of food and other products outside the agricultural sector itself. The table shows that agriculture still employs more than half of all employees 
in bioeconomy, produces $28 \%$ of the value added, and has a share of $16.5 \%$ in turnover. On the other hand, the industries producing food and drinks generate $50 \%$ of the turnover across bioeconomy, $38 \%$ of the value added, and their share in employment amounts to $25 \%$. The small share of the chemical, pharmaceutical, and plastics industries in employment is marked by a $8-9 \%$ turnover and value added. Between 2008 and 2015, the turnover of EU bioeconomy rose by EUR 141 billion, i.e., by $6.8 \%$. The growth rate of turnover in bioeconomy is driven mainly by the development of food production (an increase of 9.3\%). The higher growth rate was demonstrated by the turnover of liquid fuels, biochemicals, pharmaceuticals, and plastics. The most important countries contributing to the turnover of the EU bioeconomy were Germany (18\%), France (15\%), and Italy (13\%). In addition, Spain and the United Kingdom occupied important positions. The structure of production and turnover of bioeconomy in individual countries were fairly different. The Nordic and Baltic countries were dominated by forest biomass products, in Italy and Portugal an important role was played by bio-based products for the production of textiles, while Denmark had a high share of biochemicals.

The individual sectors of bioeconomy are characterized by different labor productivity. The highest level of turnover per employee (more than EUR 570 thousand) was demonstrated by the production of biofuels. On average, throughout the bioeconomy, this figure was at EUR 320 thousand in 2015 (Fig. 1).

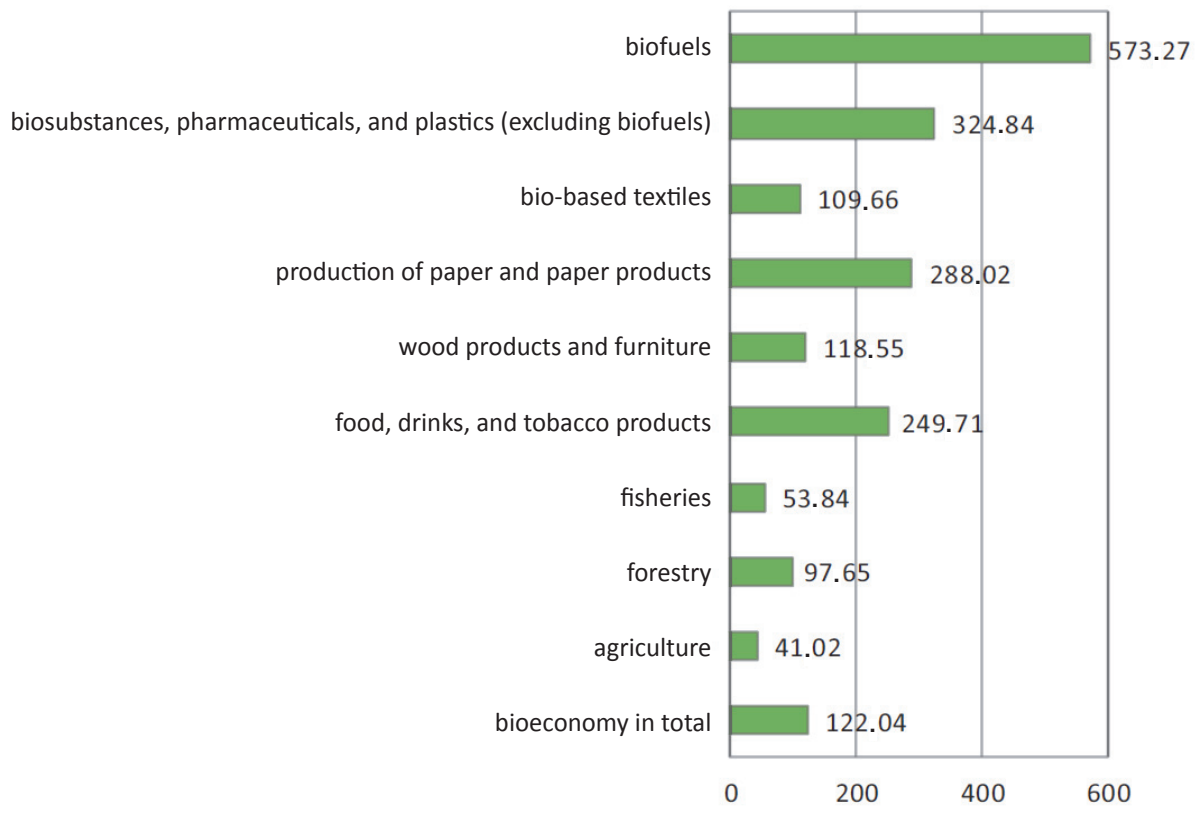

Fig. 1. Labor productivity in the EU bioeconomy sector (thousand EUR per employee) in 2015. Source: EC 2018, European Commission's Knowledge Centre for Bioeconomy. 
The 2012 European Bioeconomy Strategy, updated in 2017, provided for maximizing the contribution of bioeconomy to implementing the most important European policy priorities. It has been confirmed that this policy was based on the concept of sustainable development, part of which bioeconomy creates opportunities to achieve developmental priorities in the sphere of sustainable use of natural resources, economic efficiency, and competitiveness and to guarantee social stability. Bioeconomy, which employs $8.2 \%$ of EU labor resources and whose turnover exceeds EUR 2.3 trillion, is a key segment of the entire European economy. By 2030, a million new jobs are planned to be created, a significant percentage of them in agricultural and outlying regions. New employment should be innovative, as startups and other enterprises should play an important role here. The development of bioeconomy is essential to reduce greenhouse gas emissions and to increase the share in the production and use of renewable energy sources. It is expected that in 2020 bioenergy will account for $20 \%$ of all generated energy capacity and this share should increase to at least $32 \%$ in 2030.

Sustainable bioeconomy should support the modernization and strengthening of the EU industrial base, based on the use of research results and the application of innovation to produce new and sustainable bio-based products (biofuels, biochemicals, biopackagings). It will increase the ability to replace fossil fuels in various areas of the industry and in the construction industry and to make many new intermediates available to pharmaceutical, textile, food, and other industries. According to industry forecasts, it is expected that the demand for industrial biotechnologies will double over the next decade. Particular attention is to be paid to organizing a circular economy, through which waste, residues, and rejects can be turned into valuable products destined for the market. In 2030, the municipal waste recycling rate should reach $65 \%$ and in the case of packaging waste $-75 \%$. This will also reduce the stream of waste to be landfilled to a maximum of $10 \%$ of the total waste weight. Furthermore, it is assumed that landfilling segregated waste will be completely prohibited. Building the circular economy will have a significant impact on reducing the negative environmental impact of the life cycle of products. Households, small and medium-sized enterprises will have an important role to play in this process.

The priority of Member States should be to preserve, restore, and support healthy ecosystems and to enable and accelerate the implementation of circular economic models. As part of this approach, it will be necessary to make all tools and policies available, and to use synergies with other funds and instruments at the EU and national levels, in particular, the Common Agricultural Policy, the Common Fisheries Policy, the Cohesion Policy, and instruments supporting investment processes. 


\section{New opportunities and challenges related to bioeconomy}

\section{Strategic tasks and directions for the development of bioeconomy in the European Union}

The basis of interest in the development of the European concept of bioeconomy can be found over the last thirty years. The first document raising this issue was the so-called White Paper published in 1993, which highlighted the need to develop knowledge-based investments which included biotechnologies. In 2002, the European Commission concluded that life sciences and biotechnologies were the most prospective technologies to achieve the strategic objectives for Europe set in the 2000 Agenda. New prospects for bioeconomy were outlined by the European Commission in 2005 and in 2007 the European Council outlined a program for the development of bioeconomy for the next 20 years (Cologne Paper, 2007). Between 2010 and 2012, the concept of sustainable bioeconomy was linked to the basic document specifying the future of Europe: "EUROPE 2020 A strategy for smart, sustainable and inclusive growth" (EC, 2010). Published in 2012, the document entitled "Innovating for Sustainable Growth: A Bioeconomy for Europe" presented the concept of measures for the sustainable use of renewable biological sources in various areas of the economy (EC, 2012). The bioeconomy development plan was linked to the concurrently published research program entitled "Horizon 2020" which also addressed the need to finance research on bioeconomy and innovation from public funds.

When formulating the European concept of bioeconomy between 2010 and 2012, the European Union embedded it in the sphere of strategic measures addressing the challenges of the present day. One of the main strategic objectives is the shift from the dependence of the economy on fossil fuels to the full use of renewable energy sources and materials by integrating the activities of science, economy, state, and civil society can be achieved through (ETP, 2011):

- Accelerating the accumulation of basic knowledge, developing new technologies, and absorbing innovation. This can be achieved by intensifying research, better education, and implementation activities. A key role may be played here by the creation of network systems and the development of enterprises.

- Developing and implementing new, adequate economic structures and an efficient system to manage risks and implement international cooperation.

- Building a solid foundation for the continuity of progress by shaping research programs, supporting innovation, improving the functioning of markets, and targeting educational programs.

- Obtaining broad acceptance and social support for the implementation and continuous improvement of the concept of bioeconomy.

The European Bioeconomy Strategy developed between 2010 and 2012, the related challenges and measures, and the pillars and action plan are presented in Fig. 2. 


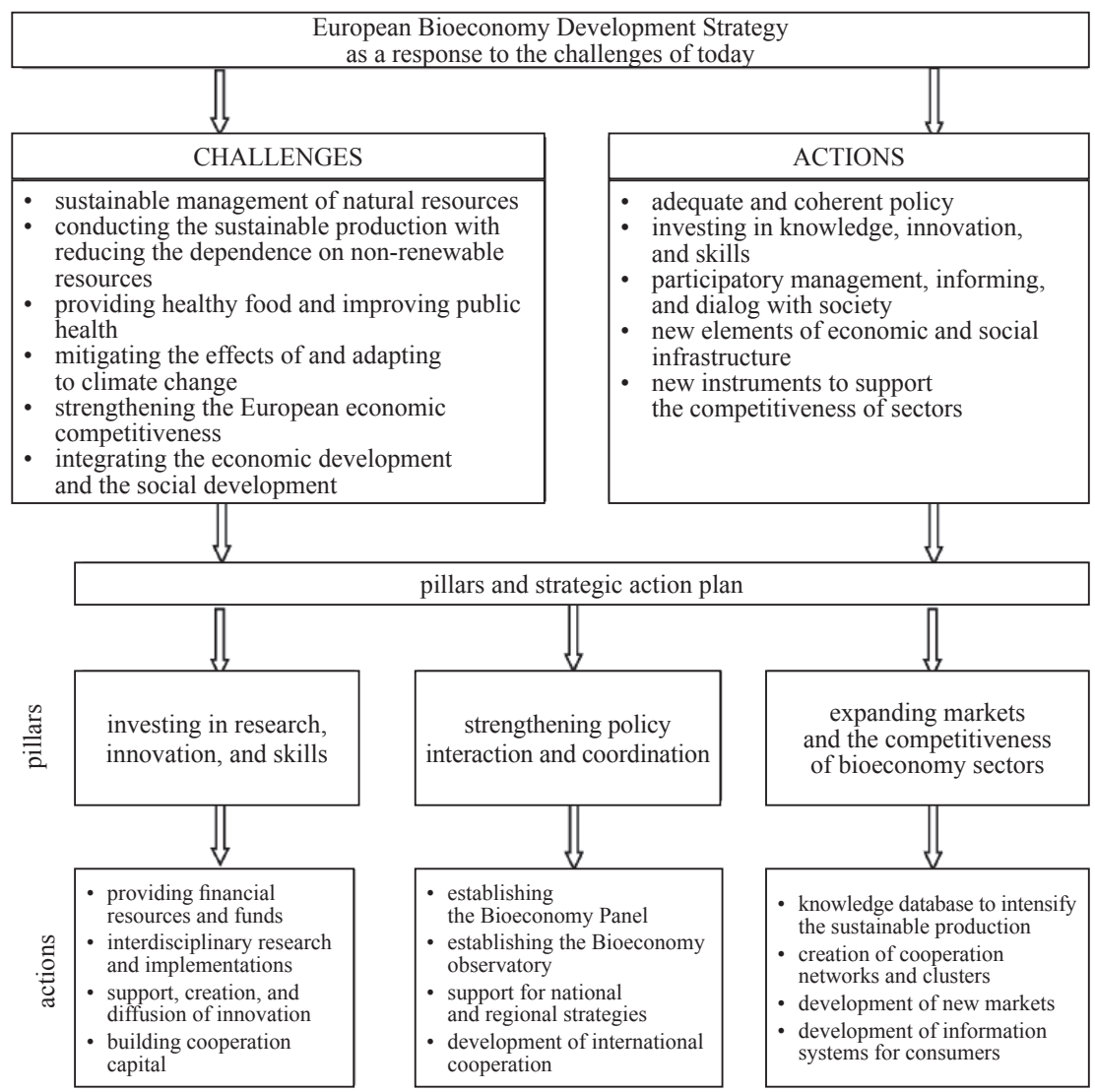

Fig. 2. European bioeconomy strategy and action plan.

Source: own study using various European Commission documents.

In 2015, during the conference "Sustainable Agriculture, Forestry and Fisheries in the Bioeconomy - A Challenge for Europe" held in Brussels, a team of experts from the Standing Committee on Agricultural Research (SCAR) presented a report stating that bioeconomy has the potential to address issues, such as: food safety, sustainable resource management, reducing the dependence on non-renewable resources, reducing adverse climate change, creating jobs, or maintaining competitiveness. Back then, new challenges related to bioeconomy were also indicated, such as the need for efficient raw material management and circular recycling from production through the use of waste disposal and treatment; building hierarchies and applying the principle of cascading in the biomass processing chain; creating and strengthening the concept of "product life cycle" and "value chains" as part of bioeconomy. All those aspects pointed to a need to strengthen the importance of sustainability in development strategies and the importance of innovation and participation in activities meant to implement these strategies. 
As a result, bioeconomy has become an important area of continuous practical interest for various European Union bodies and has been linked to the pursuit of various Community and national policies of Member States. In 2017, the European Commission published a communication addressed to various European Union bodies and entitled "A sustainable bioeconomy for Europe: strengthening the connection between economy, society and the environment", which is a kind of overview of existing achievements and an indication of directions for further development (EC, 2018).

The review of the 2012 strategy, carried out in 2017, strengthened and expanded the field of bioeconomy, which included an update made in October 2018 (EC, 2018). The new role of bioeconomy should be revealed mainly in the following areas as:

- one of the important tools for achieving the European Union's development priorities,

- the method to unlock the still untapped potential of bioeconomy,

- the area of action for sustainable circular bioeconomy,

- the method to rapidly implement local bioeconomies in Member States,

- understanding the ecological boundaries of bioeconomy.

The update of the bioeconomy development strategy in 2017 pointed to the topicality of the five previously set objectives:

- ensuring food and nutrition security,

- sustainable management of natural resources,

- reducing the dependence on non-renewable resources,

- mitigating the effects of and adapting to climate change,

- strengthening European competitiveness through job creation.

The achievement of the first strategic objective resulted from the fact that agricultural production as well as food production and supply systems are responsible for $3 / 4$ of the total employment in bioeconomy and about $2 / 3$ of the turnover of bioeconomy. Guaranteeing the sustainable functioning of these systems creates a number of difficulties that result from population trends, changes in nutrition practices and consumption patterns, the lack of rationality in biomass management, and the growing problem of waste and climate change. The process of transition to sustainable and healthy eating, resource-efficient circular food production and management systems, and the rational use of human resources must be accelerated. This, including the better use of raw materials, by-products, and waste for the production of new bio-based products, should reduce the risk of management, provide the desired level of income for rural populations, and reduce the phenomenon of social exclusion.

Sustainable management of natural resources is an objective which is still important. The degradation of ecosystems continues to progress despite various remedial measures. In particular, ecosystems providing food and water security, and those vulnerable to degradation due to climate change must be strengthened. An impor- 
tant task is the reduction in gas emissions as well as carbon removal processes. Despite partial inhibition of unfavorable trends, preserving biodiversity and increasing the productivity of healthy ecosystems require constant attention. As part of this objective, it is important to build a system for monitoring and forecasting the state of natural resources.

Reducing the dependence on non-renewable resources, regardless of their origin, is of key importance for achieving the EU energy and climate targets and is associated mainly with tapping the potential of biomasses. Biomass includes various plants, plant fractions, or residues resulting from production processes as well as waste. For classifying a biomass, we may use various criteria such as origin (land, sea, rural, urban), production (forest, agricultural, or municipal), properties (humidity, biochemical composition), and end-use (energy, food, chemicals, materials). Agriculture is one of the major sources of biomass in the form of agricultural raw materials used for the production of food, industrial products, and energy. The total production of agricultural biomass in the EU has been estimated at 817 million tons of dry matter, of which 53\% are main products and $47 \%$ are residues. Agriculture, which underpins the ability of the food market to function, is becoming an important source of bioenergy for the production of which both waste and main products are used. Over the last 20 years, the production of liquid biofuels has been steadily growing, reaching a level of 156 billion liters in 2017. The total production of biomass in EU agriculture has slightly increased over the last 25 years (Gołębiewski, 2019). It is envisaged that bioenergy will become an important part of the EU energy mix in 2030. To achieve this, the following are necessary: strengthening the biotechnology sector, the symbiosis of industries, and the implementation of bioprocess innovations in industries subject to greening processes. The production of new innovative products in this circular economy should be practised in various fields, resulting in a general reduction in generated waste.

Mitigating the effects of and adaptating to climate change are an important challenge for the current generation. Europe has made ambitious commitments to reduce greenhouse gas emissions, the fulfilment of which depends on implementing a sustainable circular bioeconomy. One of the ways to achieve this objective may be the introduction of innovative crops fostering carbon sequestration by the soil.

Strengthening the European competitiveness and creating jobs is a major policy objective in the implementation of the bioeconomy program. Here, attention is paid to the implementation of innovations and supporting the market for bio-based products, inter alia, through the public procurement system, creation of standards and regulations, policy on energy sources, and shaping of energy prices and carbon allowances. All these activities are aimed at transforming the European industry and enhancing its competitiveness on a global scale. Bioeconomy should become a tool for improving the effectiveness of regional policy, an opportunity to strengthen the territorial cohesion of outlying regions, and a driver stimulating the development of local systems in rural areas. In this regard, bioeconomy is becoming an important tool for meeting the demands specified in the Cork 2.0 Declaration of 2016. 


\section{New areas of action for sustainable bioeconomy}

Three main areas of action have been added to the five objectives retained from the 2012 strategy in the bioeconomy development strategy updated in 2018, which are as follows:

- developing, strengthening, and scaling up sectors using biotechnologies,

- rapid deployment of local bioeconomies across Europe,

- protecting the ecosystem and understanding the ecological boundaries of bioeconomy.

The proposed measures are based on the previously introduced institutional solutions and research under the Horizon 2020 program and on measures supporting innovation. Bioeconomy has been considered in a systemic manner and the action plan covering multiple sectors and policies related to bioeconomy, and facilitating coherence and synergies was intended to provide trade-offs with regard to the competitive use of biomass and the effective attainment of various policy objectives, also on an international (non-EU) scale.

Under the first area, six measures have been identified, related to research and scientific, demonstration, and implementation activities; the creation of a targeted financial instrument in the form of a thematic investment platform for implementing, without undue risk, the innovation of a sustainable circular bioeconomy with a budget of EUR 100 million; establishing a system of standards and labels for biobased products; their dissemination and promotion; facilitating the emergence and development of new biorefineries; and restoring the purity and quality of waters, in particular, by clearing water bodies from pollution with plastics.

The European Commission focused on the rapid deployment of local bioeconomies in Member States. In some countries and regions, especially in Central and Eastern Europe, the potential for the production of biomass and for the use of waste is high and not fully tapped. Therefore, the Commission is going to develop a strategic implementation program that will provide a long-term vision of the methods of using and scaling up bioeconomy in a sustainable and circular manner, both in the sphere of agri-food, land, and marine systems, in the forestry and wood product sectors, as well as in aquaculture systems organized in various conditions and in the processing industry using biotechnological processes. This production is to be located in both rural and suburban areas, coastal areas, and cities. Currently, five pilot project drafts have been prepared for coastal areas, agricultural areas, 10 European cities, agroforest areas, or the research and development sphere. The Blue Economy project is aimed at unlocking the potential of seashores and islands, including the Baltic Sea basin, using the European Maritime and Fisheries Fund. The CAP provides for the promotion of an inclusive bioeconomy in rural areas. In cities, attention will be paid to waste management using new bioeconomy technologies. In many areas, programs aimed at sequestering carbon dioxide in soils and reducing gas emissions in the livestock sector and the use of fertilizers will be promoted. Moreover, "living laboratories" will be set up to test biotechnological innovations 
and to provide information and data for research under the Horizon 2020 program. A systemic and cross-cutting approach to bioeconomy also requires the introduction of new forms of education, the acquisition of practical skills at various levels of vocational and higher education, and the development of relations between science and economic practice. This should lead to a better understanding of the ecological possibilities, but also the boundaries of bioeconomy, the development of an appropriate monitoring system, the collection and analysis of more data, and the creation of thematic information databases.

\section{Summary}

Agriculture is subject to continuous transformation, influence by internal factors inherent in the sector itself, as well as of factors stemming from the closer and further national environment, and the impact of Community policies and global processes. An important feature of these transformations is the shrinking role of agriculture in the economy, the growing strength with non-agricultural sectors of the rural economy, the continuous technological and organizational progress, the growing dependence on cooperation with other agribusiness sectors, and the protection and financial support provided by agricultural policies. An important task, in the light of these changes, is to protect the social, family nature of agriculture, to prevent the deagrarization of rural areas, to preserve the values of the natural and cultural environment, and to strengthen international competitiveness.

It has become a canon that the agricultural development and the functioning of rural areas in Poland, and in other European Union countries, take place in accordance with the principles of sustainable development ensuring a balance of economic, social, and environmental governance. However, there are many possible methods and ways to implement sustainable development. The concept of bioeconomy may become one with great promise. Developed for more than twenty years in the theoretical sphere and for fifteen years in the field of practical preparation and implementation, it has become both a new analytical and cognitive concept and a multisectoral field of management based on biomass and various modern processing technologies, in particular, biotechnologies with new materials and devices using knowledge and cooperation with science (Von Braun, 2015). Bioeconomy suggests shifting from an economy based on traditional production resources to an economy based on renewable resources, recycling, resource savings, and respect for the natural environment. An especially promising form is sustainable circular bioeconomy, based on precisely designed reuse of resources, in particular, of renewable resources, and minimizing waste generation and negative externalities.

The development of bioeconomy can bring a number of environmental, social, and economic benefits to both agriculture and to other sectors of the economy. The environmental benefits may include the efficiency of using resources, materials, and energy and a reduction in emissions of pollutants and waste. Among the social benefits, of the utmost importance is the increase in employment and activation of cooperation among enterprises and sectors, as well as better satisfaction of 
social needs. The economic benefits consist in improving management efficiency, mainly by reducing the consumption of non-renewable raw materials, lower costs of using material inputs and energy, and better management of production cycles. The development of these production systems may also encounter unfavorable phenomena and limitations of a technical, organizational, social, or political nature. For example, competition for resources (land, technologies, biocomponents, competences) among enterprises, sectors, or regions developing specialized production systems may grow, and new and unknown environmental risks may also appear.

The implementation of new production systems requires informed support and the development of appropriate strategies, policies, and action plans. The strategy for the development of bioeconomy and the circular economy has been preliminarily developed at the European Union level and is continuously complemented. Several dozen countries all over the world have also developed national strategies and plans for the development of bioeconomy (Dietz, Borner, Forster and von Braun, 2018). Poland does not have a comprehensive, multi-directional strategy in this area yet, although certain elements are emerging in the individual sectors of the economy. What is needed to make the undoubtedly necessary development in production systems appropriately using biomass and other biological raw materials, is an interdepartmental approach, development of research (Maciejczak, 2018) and training of human resources, adequate system of subsidies, adequate location and regional policies for bio-based industries, and social education teaching the conditions and need for transitioning to an economic system based on renewable sources. 


\section{References}

Adamowicz, M. (2017). Bioeconomy - Concept, Appliction and Perspectives. Problems of Agricultural Economics/Zagadnienia Ekonomiki Rolnej, nr 1(350), pp. 29-49. Retrieved from: https:// doi.org/10.5604/00441600.1232987.

Banioniene, J., Dagiliene, L. (2007). Circular Economy: Technologies for Circulation. In: A.P. Balcerzak, I. Pietryka (ed.), Proceedings of the $9^{\text {th }}$ International Conference on Applied Economics Contemporary Issues in Economy: Economics (pp. 38-49). Toruń: Institute of Economic Research.

Chciałowski, M., Stolarczyk P., Tuka, P. (2016). Wyzwania biogospodarki względem wskaźników zrównoważonego rozwoju Unii Europejskiej. Roczniki Naukowe SERiA, XVIII(1), pp. 28-34.

Cologne Presidency (2007). En Route to the Knowledge-Based Bio-Economy. Retrieved from: https:/dechema.de/dechema_media/Downloads/Positionspapiere/Cologne_Paper.pdf.

Dietz, T., Borner, J., Forster, J.J., von Braun, J. (2018). Governance of the Bioeconomy: A Global Comparative Study of National Bioeconomy Strategies. Sustainability, 10(9), 3190. Retrieved from: https://doi.org/10.3390/su10093190.

EMAF (2012, 2013, 2015). Towards the Circular Economy Vol. 1, 2, 3: An Economic and Business Rationale for an Accelerated Transition. Retrieved from: https://www.ellenmacarthurfoudation.org/business/reports.

Enriquez, J., Martinez, J. (1998). Genomies and the World's Economy. Science Magazine, Vol. 281, No. 5379, pp. 925-926.

ETP (2011). The European Bioeconomy in 2030. Delivering Sustainable Growth by Addressing the Grand Societal Challenges, The White Paper. Retrieved from: http:/www.becoteps.org.

Europa Bio (2011). The Bioeconomy for Europe: Innovating for Sustainability. Retrieved from: https://eurocalendar.eu/.

European Commission, DG Research (2005). FP 7 Theme 2. Food, Agriculture, Fisheries and Biotechnology, Work Programme.

European Commission, DG Research (2006). FP7 Theme 2. Food, Agriculture, Fisheries and Biotechnology, 2007 Work Programme.

European Commission (2010). Europe 2020. A Strategy for Smart, Sustainable and Inclusive Growth. Communicatio from the European Commission. Retrieved from: https://eur-lex. europa.eu/legal-content/en/ALL/?uri=CELEX\%3A52010DC2020.

European Commission (2010). The Knowledge - Based Bioeconomy in Europe. Achievements and Challenges, Contemporary Report.

European Commission, DG Research (2011). Bio-based economy in Europe: State of play and future potential - part 2. Summary of the position papers received in response to the European Commission' s public on-line consultation.

European Commission (2012). Innovating for Sustainable Growth. Bioeconomy for Europe. COM (2012) final.

European Commission (2014). Towards a Circular Economy. A Zero-Waste Program for Europe. Retrieved from: https://ec.europa.eu/environment/circular-economy/pdf/circular-economy-communication.pdf.

European Commission (2018). A Sustainable Bioeconomy for Europe: Strenghtening the Connection Between Economy, Society and the Environment. Retrieved from: https://ec.europa. eu/research/bioeconomy/pdf/ec_bioeconomy_strategy_2018.pdf.

European Commission (2019). The European Green Deal. Retrieved from: https://eur-lex.europa.eu/legal-content/EN/TXT/?uri=COM\%3A2019\%3A640\%3AFIN.

European Commission (2020). A Farm to Fork Strategy for a Fair, Healthy and Environmentallyfriendly Food System. Retrieved from: https://ec.europa.eu/info/sites/info/files/communication-annex-farm-fork-green-deal_en.pdf. 
GBS (2015, 2018). Global Bioeconomy Summit, Berlin. Retrieved from: https://gbs2015.com/the-summit-i/

Geissdoerfer, M., Savaget, P., Bocken, N.M.P., Hulting, E.J. (2017). The Circular Economy A New Sustainability Paradigm?. J. Clean. Prod., 23, pp. 753-768. Retrieved from: https://doi. org/10.1016/j.jclepro.2016.12.048.

GFFA (2015, 2018, 2020). Global Forum for Food and Agriculture, Berlin. Retrieved from: http://gffa2015.com.

GIOŚ (2019). Biogospodarka a gospodarka w obiegu zamkniętym. Retrieved from: http://www. gios.gov.pl/pl/eea/aktualnosci/produkty/599-biogospodarka-a-gospodarka-o-obiegu-zamknietym.

Gołębiewski, J. (2013). Zrównoważona biogospodarka - potencjat i cynniki rozwoju. IX Kongres Ekonomistów Polskich, 1-13.

Gołębiewski, J. (2019). Systemy żywnościowe w warunkach gospodarki cyrkularnej. Studium porównawcze krajów Unii Europejskiej. Warszawa: Wydawnictwo SGGW.

Grupa Lizbońska (1986). Granice Konkurencji. Warszawa: Poltext.

Hall, R. Ernsting, A., Lovera, S., Alvarez, I. (2012). Bio-economy versus Biodiversity. Global Forest Coalition. Retrieved from: https://globalforestcoalition.org/wp-content/uploads/2012/04/Bioecono-vs-biodiv-report-with-frontage-FINAL.pdf.

Jongeneel, R. (2020). The CAP revisited: A Reflection on Challenges and Options. Zagadnienia Ekonomiki Rolnej/Problems of Agriculture Economics, No. 2(363), pp. 7-13.

Leitao, A. (2016). Bioeconomy: The Challenge in the Management Resources in the $21^{\text {st }}$ Century. Open Journal of Social Sciences, 4(11), pp. 26-42. Retrieved from: https://doi.org/10.4236/jss. 2016.411002.

Maciejczak, M., Hofreiter, K. (2013). How to Define Bioeconomy. Roczniki Naukowe SERiA, $X X V(4)$, pp. 243-248.

Maciejczak, M. (2018). Wyzwania rozwoju i kierunki badań bioekonomii. Roczniki Naukowe SERiA, XX(1), pp. 94-99.

McCormick, K., Kautto, N. (2013). The Bioeconomy in Europe: An Overview. Sustainability, 5(6), pp. 2589-2608. Retrieved from: https://doi.org/10.3390/su5062589.

Murray, A., Skane, K., Haynes, K. (2017). The Circular Economy: An Interdiciplinary Exploration of the Concept and Application in a Global Context. J. Bus. Eth. 140, pp. 369-380. Retrieved from: https://doi.org/10.1007/s10551-015-2693-2.

NORDEN (2015). Nordic Bioeconomy. Retrieved from: http://www.norden.org/en/theme/nordic-bioeconomy.

OECD (2006). The Bioeconomy to 2030: Designing a Policy Agenda. Retrieved from: http://www. oecd.org/science/emerging-tech/34823102.pdf.

OECD (2009). The Bioeconomy to 2030: Designing a Policy Agenda, Main Findings. Retrieved from: https:/www.oecd.org/futures/long-termtechnologicalsocietalchallenges/thebioeconomyto2030designingapolicyagenda.htm.

Ratajczak, E. (2013). Rolnictwo i leśnictwo w świetle koncepcji biogospodarki. Retrieved from: www.pte.pl/kongres/referaty.

Soliwoda, M., Wieliczko, B., Kulawik, J. (2020). Gospodarka w cyklu zamkniętym a zrównoważenie agrobiznesu. Zagadnienia Ekonomiki Rolnej/Problems of Agriculture Economics, $n r$ 1(362), pp. 3-13. Retrieved from: https://doi.org/10.30858/zer/110742.

Von Braun, J. (2015). Bioeconomy - Science and Technology Policy to Harmonize Biologization of Economies with Food Security. In: D. Sahn (ed.). Fight against Hunger and Malnutrition (pp. 240-262).London:OxfordUniversityPress.Retrievedfrom:https://doi.org/10.1093/acprof: oso/9780198733201.003.0011.

White House (2012). National Bioeconomy Blueprint. Washington DC. 


\title{
BIOGOSPODARKA JAKO KONCEPCJA ROZWOJU ROLNICTWA I AGROBIZNESU
}

\begin{abstract}
Abstrakt
Przedmiotem opracowania jest koncepcja biogospodarki jako nowego, łacznego sposobu postrzegania funkcjonowania różnych sektorów gospodarki narodowej wytwarzajacych i przetwarzajacych zasoby biologiczne. Na podstawie literatury i dokumentów instytucji europejskich przedstawiono biogospodarke jako koncepcję teoretyczna, omówiono jej istotę i sposoby definiowania, zakres i rozmiary biogospodarki oraz możliwości i zagrożenia związane z biogospodarka. Pokazano kierunki i obszary działań oraz aktualne strategie wspierania rozwoju zrównoważonej biogospodarki $i$ jej powiazań z modelem gospodarki o obiegu zamkniętym. Z przeprowadzonych analiz wynika, że biogospodarka stanowi obiecujaca koncepcje rozwoju rolnictwa, agrobiznesu, leśnictwa i innych sektorów wytwarzajacych i wykorzystujacych biosurowce. Dla wykorzystania realnych możliwości tkwiacych $w$ biogospodarce niezbędne jest posiadanie krajowych $i$ regionalnych strategii rozwoju biogospodarki oraz opracowanie sprawnego systemu projektowania i zarządzania na szczeblu przedsiębiorstw, sektorów i układów regionalnych.
\end{abstract}

Słowa kluczowe: biogospodarka, gospodarka w obiegu zamkniętym, zrównoważony rozwój, strategie rozwoju.

Accepted for print: 21.12.2020.

Unless stated otherwise all the materials on the website are available under the Creative Commons Attribution 4.0 International license.

Some rights reserved to the Institute of Agricultural and Food Economics - National Research Institute.

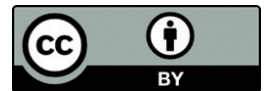

